\title{
E-book limitation with library portable document format java script for accessing digital library
}

\author{
Harliyus Agustian ${ }^{1, *}$, Agung Nugraha ${ }^{2}$ \\ ${ }^{1,2}$ Informatics Study Program, Adisutjipto Institute of Aerospace Technology, Indonesia
}

\begin{tabular}{l}
\hline \hline Article Info \\
\hline Article history: \\
Received April 14,2021 \\
Accepted May 24, 2021 \\
Published June 15, 2021 \\
\hline
\end{tabular}

\section{Keywords:}

E-library

LibraryPDF.js

PDF Viewer

Security

\begin{abstract}
The function of the Adisutjipto Institute of Aerospace Technology (ITDA) library is to provide borrowing and reimbursement services for books insured by members of the library. The books which increase in number each year occupy a lot of space in the library, it is therefore necessary to study it so that the form of this book is no longer physical but digital or paperless to be able to be stored on a server computer. This form of library is known as a digital library or e-library. The electronic library is a modern library as a place which provides a source of educational information with more convenience and security. The flow in the application is not very different from the flow in the manual library. Security becomes an important part of an application, by limiting network access, accessing PDF documents and implementing PDF Viewer using the PDF.js library by rendering PDF documents on a canvas capable of blocking illegal downloads. Based on the test results, the electronic library application can work properly. The speed of opening a PDF document is influenced by the speed of the server, the content contained in the PDF and the size of the PDF file.
\end{abstract}

\section{Corresponding Author:}

Harliyus Agustian,

Informatics Study Program,

Adisutjipto Institute of Aerospace Technology,

Blok-R Lanud Adisutjipto, Yogyakarta, Indonesia.

Email: "harliyus@itda.ac.id

\section{INTRODUCTION}

Libraries in Indonesia are found in schools and higher education institutions, both public and private, as well as central and regional governments at the provincial and municipal or district levels. Some Crown corporations, private and foreign also have libraries. This library has the form of a conventional or analog library, providing reading and borrowing services of books in physical form. In addition to conventional libraries, some institutions and companies also supplement books which can be read and borrowed in the form of electronic books, also called electronic books [1]. The ebook as a digital collection can be better managed with an unconventional library, the library is known as a digital library [2].

In addition to books, digital libraries are also used to provide open access services over the Internet. This digital collection of scientific articles published free of charge in online journals is free. Some online journal managers charge readers for access to articles that become their digital collections. Several universities and libraries in Brazil are forming a consortium to overcome the burden of access costs for digital collections in online journals that are not open access [3]. In addition to reducing the cost of access, cooperation between universities in one country or different countries is being set up in order to create a digital library which has a unique digital collection, including Aramaic languages in Syria [4].

A consortium of university libraries is also being established in Italy, for various electronic resources in the form of licenses or digital products [5]. Digital products can be digital books or scientific articles from online journals, but they can also take the form of conference results and repositories which are maintained in a digital library as has been done in Ukraine [6]. In addition to hosting collections of objects in digital form, the existence of digital libraries is also used to develop existing research, namely the humanities in digital form as is done in China [7] and America [8].

Digital libraries are built physically and not physically, physical digital libraries need space to store hardware and supporting computer networks. Not physically, digital libraries need software that can be used 
to store and display e-books and record user data and user activities in digital libraries. Software to provide digital library services can be created on the web [9] and based on mobile devices or services such as Android or iPhone. Some software for digital libraries must be purchased at a fairly high price, but there is also software for open source digital libraries [10] which should be developed more precisely according to the needs of its users. In addition to computer hardware and software as well as computer networks, digital libraries also require a resource that is required, namely books in electronic form or electronic books in portable document format (PDF) which users can access wherever they are if they are placed on an Internet network such as on google book [11]. With unrestricted access via the Internet, it is hoped that libraries can make important contributions to the global community who need information and literacy effectively and efficiently [12] and who are not physically linked when 'they access the library [13]

The development of digital libraries in Indonesia by technological equipment, software and computer networks is not an obstacle to its implementation, but several obstacles arise from a lack of understanding of the rules and legislation governing copyright [14]. The digital library built in the STTA library uses a computer network that is separate from the main network in the book circulation service to provide more restrictions and security via a Virtual LAN [15]. The components of digital products to which users of digital libraries later access must be assured that they do not violate these laws. So, in this study aims to restrict access to digital libraries so as not to violate existing regulations in Indonesia by creating software for digital libraries using PDF libraries.

\section{RESEARCH METHOD}

In Figure 1, we can see the method used in building software for digital libraries to supplement conventional libraries at the Adisutjipto Institute of Aerospace Technology (ITDA) in Yogyakarta. This method allows for departmentalization and control. the process of developing the model phases one by one, so as to minimize errors that might occur. The first thing to do is to interview the contact person as responsible for managing the library of the Adisutjipto Institute of Aerospace Technology to obtain authentic data. Next, collect data from various literatures such as books, journals and other sources related to electronic libraries and the creation of websites. In addition, analyze the software and hardware requirements that will be used in this research. Monitoring of the design of the software that will be used by the ITDA library.

Once the software is in prototype form, the next step is to test it to see if the system has met the requirements criteria. This test will test the application system that is built as a whole if the built system can work well. After going through the testing and improvement stages, the software is then applied to complete the existing conventional library.

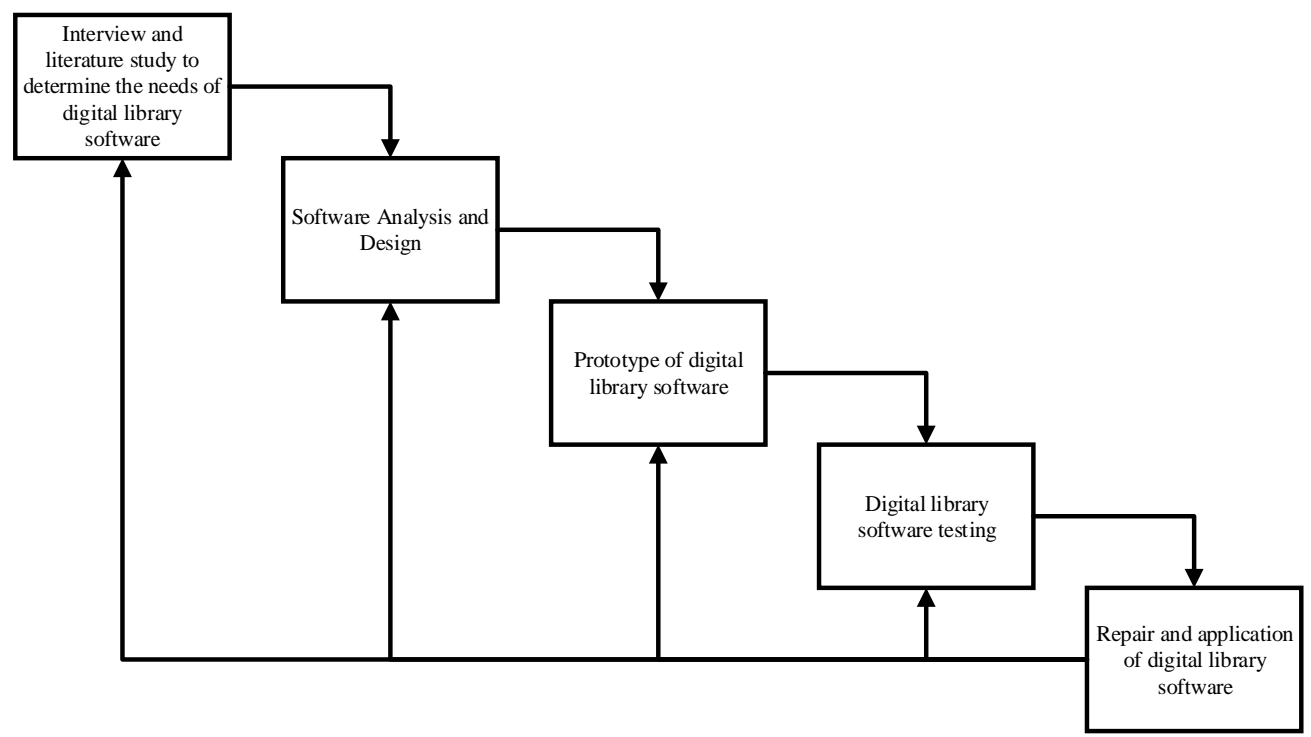

Figure 1. Waterfall method used as a research method

\section{RESULTS AND ANALYSIS}

\subsection{Software analysis}

Level 0 data flow diagram in figure 2, there are 8 main processes, namely the first process is the user login process, the user login is done by matching the nim and password in the table members. The second process is the reading process, the reading process is carried out by the user by checking the data of the electronic book in the catalog table and by storing the reading history on the reading table. The third process is the librarian login process by matching the username and password to the admin_users table. 
The fourth process is the process of processing the book data by entering the book data and it will be stored in three tables, namely the catalog table, catalog_category and also the stock_buku table. The fifth process is the process of processing category data by entering the category data and will be stored in the category table and the catalog_category table. The sixth process is the process of processing member data by entering member data into the member table. The seventh process is the process of processing profile data by entering the administrative data into the admin_users table. The eighth process is the return process, in this process can be performed by the user or by the librarian with the data contained in the reading table, then the stock will be returned to the stock_book table.

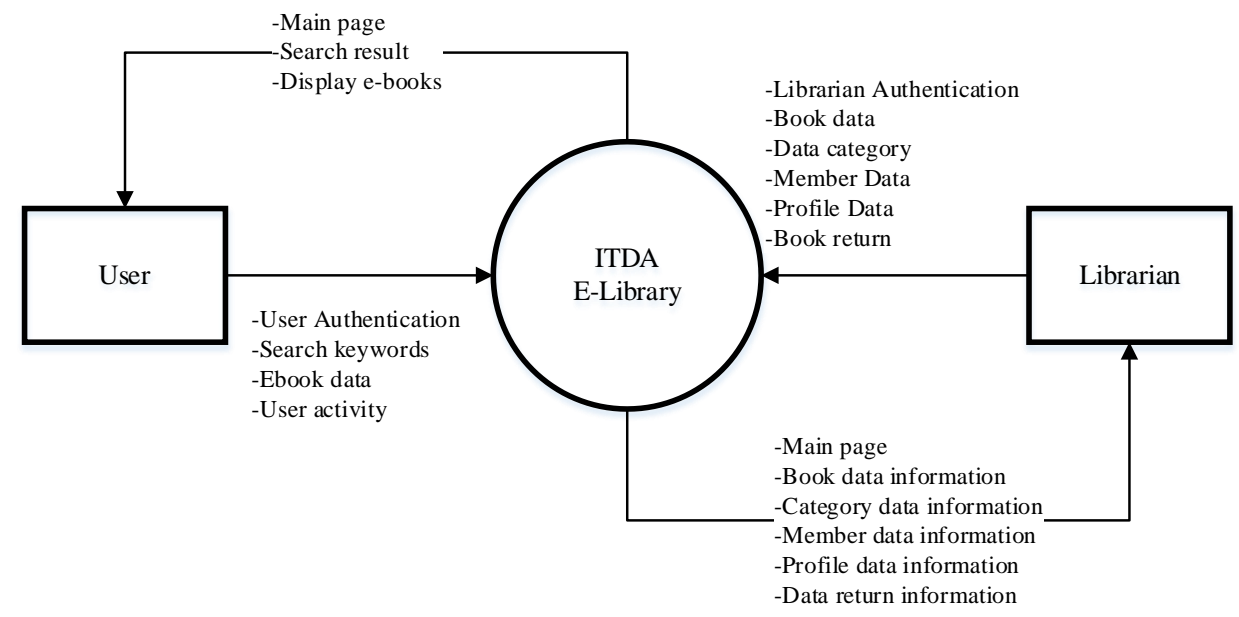

Figure 2. Context diagram of e-library application

\subsection{Software testing}

Design and software development using a WEB-based programming language, the software for digital libraries was completed as a prototype, as shown in the figure 3 . This software has two users, the first as administrator responsible for providing and filling in the data. required by the reader, as well as users who, as readers, can view and read e-books using the supplied computer. For readers, in this case, ITDA students, can start by visiting the main page as shown in Figure 3.

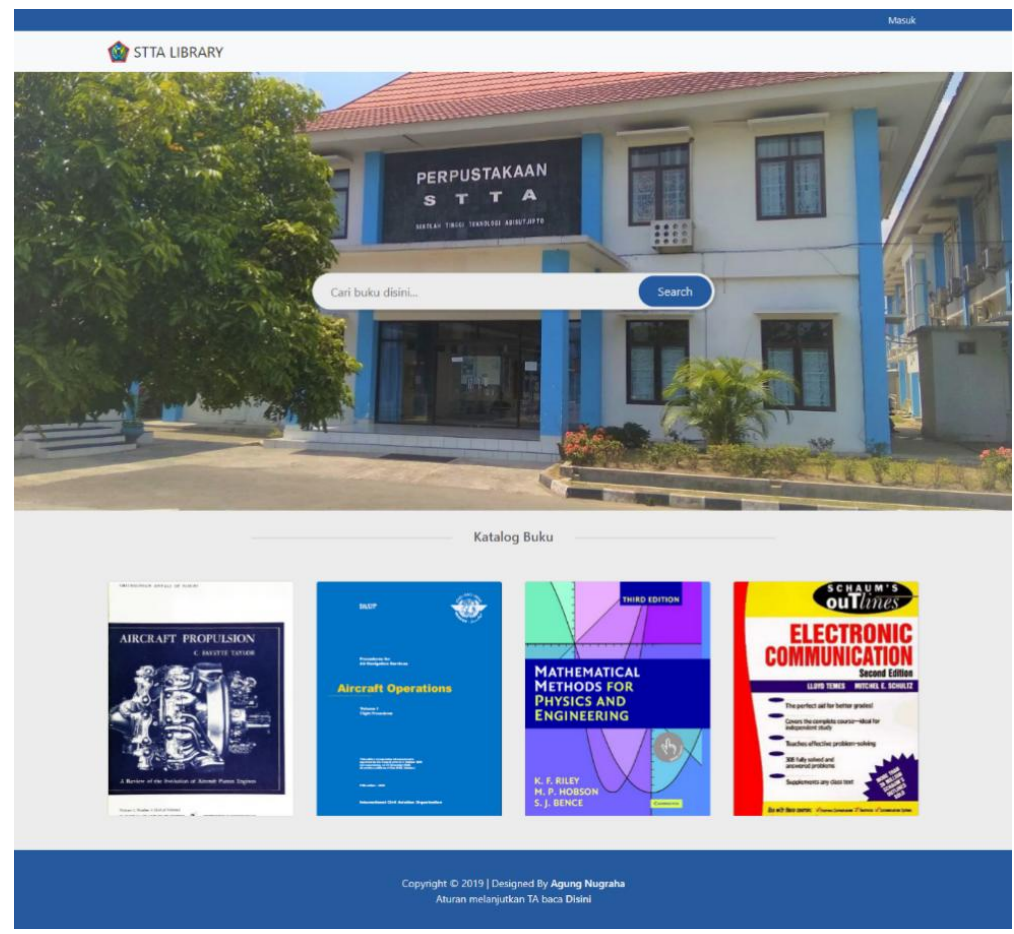

Figure 3. Main page digital library in itda 
The home page is the main page on the reader side when you first open the electronic library application. On this page there is a list of books that can be selected and read by students provided that the book is still in stock and there is a pdf. On this page also provides a search menu that can be used to quickly search for books with the keyword title, author, publisher and issn. To see the details of a book, simply point the cursor on the book and the detail button will appear, when the button is pressed, it will look like Figure 4 . The read button will appear when a student has connected.

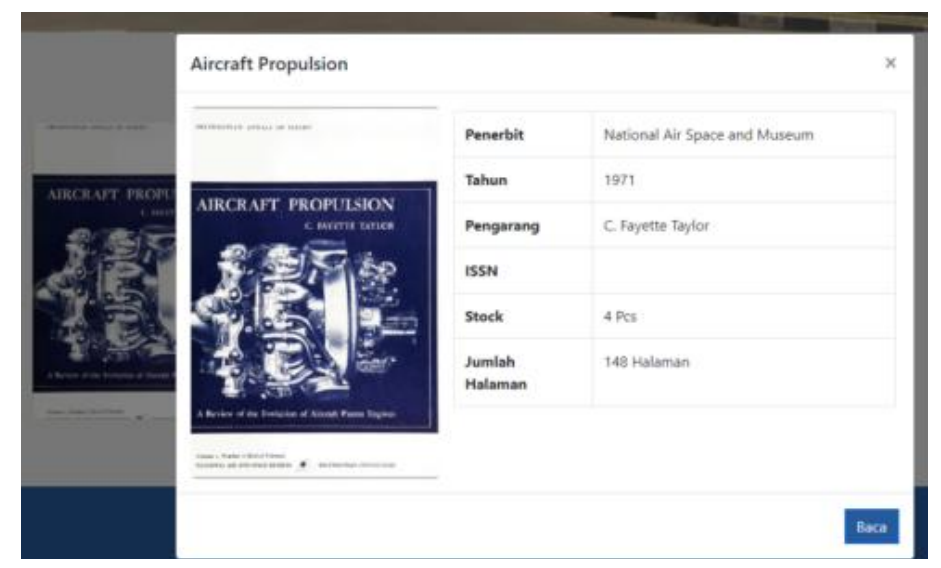

Figure 4. Book details homepage

If the reader wants to read the e-book, then the next step is to press the read button which will display the PDF reading page as illustrated in Figure 5. On the pdf reading page is a linked page to the ebook / pdf downloaded by the administrator. When the students press the read button, the process is done by displaying the PDF file using the PDF.js library and placing it in the canvas, which is the html tag. This process is intended to ensure that the PDF files displayed on the browser remain secure and cannot be stored as a whole. On the pdf reading page there is also a button, which can be used to flip the book over, as the reading process reduces the stock.

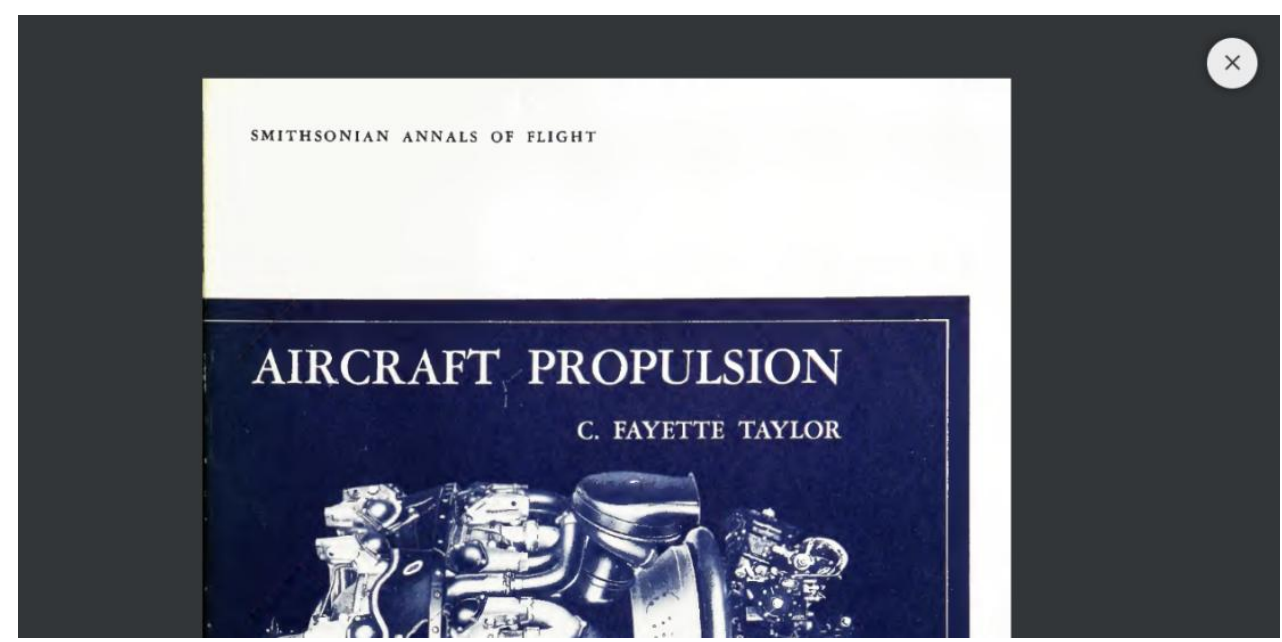

Figure 5. Read PDF page

\subsection{Testing the speed of access and software security}

Test the speed of access and security in accordance with existing regulations in Indonesia. Speed testing is a test to determine the level of speed in a system in carrying out the process. In this test is a pdf open speed test, where the speed level is calculated when the pdf is first opened ie the first page to the last page. The results of pdf open speed testing are divided into 3 based on pdf document size, connection type, and the content contained in the pdf. Table 1 is the result of a speed test when opening a pdf depending on the size of the pdf document and the type of connection used. The tests are carried out using five PDF files with different file sizes and using 2 types of connections, namely the local area network (LAN) and the access point 
Table 1. Testing speed of opening pdfs based on file size and connection type

\begin{tabular}{clcc}
\hline \multirow{2}{*}{ No. } & \multicolumn{2}{c}{ PDF File Size } & \multicolumn{2}{c}{ Speeds } \\
& & Access Point \\
\hline 1 & $1.313 \mathrm{~KB}$ & 11.481 second & 13.083 second \\
2 & $3.530 \mathrm{~KB}$ & 13.031 second & 17.839 second \\
3 & $7.621 \mathrm{~KB}$ & 25.241 second & 30.872 second \\
4 & $8.680 \mathrm{~KB}$ & 46.704 second & 55.832 second \\
5 & $14.034 \mathrm{~KB}$ & 89.875 second & 95.523 second \\
\hline
\end{tabular}

Table 2 is a pdf opening speed test based on the content contained in the pdf in the form of images and writing.

Table 2. Testing speed of opening pdf based on content

\begin{tabular}{clccc}
\hline No. & \multicolumn{1}{c}{ PDF Document } & Figure & Teks & Speeds \\
\hline 1 & Microelectronic Devices and Circuits & $84.00 \%$ & $12.75 \%$ & 52.431 second \\
2 & Airframes and Systems & $52.00 \%$ & $38.97 \%$ & 50.664 second \\
3 & Operation Of Aircraft Part I & $0.00 \%$ & $80.28 \%$ & 11.481 second \\
\hline
\end{tabular}

Security tests are tests performed to determine the security level of a system. In the e-library application, a security test is carried out to test security on the pdf which will be opened by the students. Tests are performed using third-party software which is download manager software to detect whether open pdf files can be downloaded using download manager software, the results test can be viewed in Table 3.

Table 3. PDF security testing

\begin{tabular}{lcc}
\hline Software & PDF viewer e-library & PDF viewer browser \\
\hline EagleGet & {$[\mathrm{x}]$} & {$[\mathrm{x}]$} \\
Free Download Manager & {$[\mathrm{x}]$} & {$[\mathrm{x}]$} \\
Internet Download Accelerator & {$[\mathrm{x}]$} & {$[\mathrm{x}]$} \\
BitComet & {$[\mathrm{x}]$} & {$[\mathrm{x}]$} \\
Internet Download Manager & {$[\mathrm{x}]$} & {$[\mathrm{x}]$} \\
\hline
\end{tabular}

Information:

Internet Download Manager

[ $\mathrm{x}$ ] Cannot be downloaded using third-party software

The ITDA Digital Library software consists of two systems, the first is admin, that is to say a system operated by the administrator or the librarian to manage data from electronic books and others. The second system is a user-side system operated by students visiting the library, this system works to search for e-books and read e-books. In the electronic library application, several types of tests have been carried out to determine whether the application to be used and to be applied in the library can function correctly or not.

In the first test which tests the blackbox by testing the functions of the application with several types of test scenarios. The tests are performed on the administrator and user side, and according to the test results, the test results work well. The PDF viewer used in the electronic library application uses the PDF.js library and is equipped with a token authorization to prevent the downloading of open electronic books in the browser. The second test tests the speed of opening the pdf from the first page to the last page of the pdf. The test results can be found in Tables 1 and 2. This speed test is divided into 2 tests, namely the speed test based on file size and connection type, and the speed test based on content contained in the pdf in the form of images and text. All the speed tests that have been tested work well with different results obtained on each pdf document illustrated in Figure 6. 


\section{PDF file open speed}

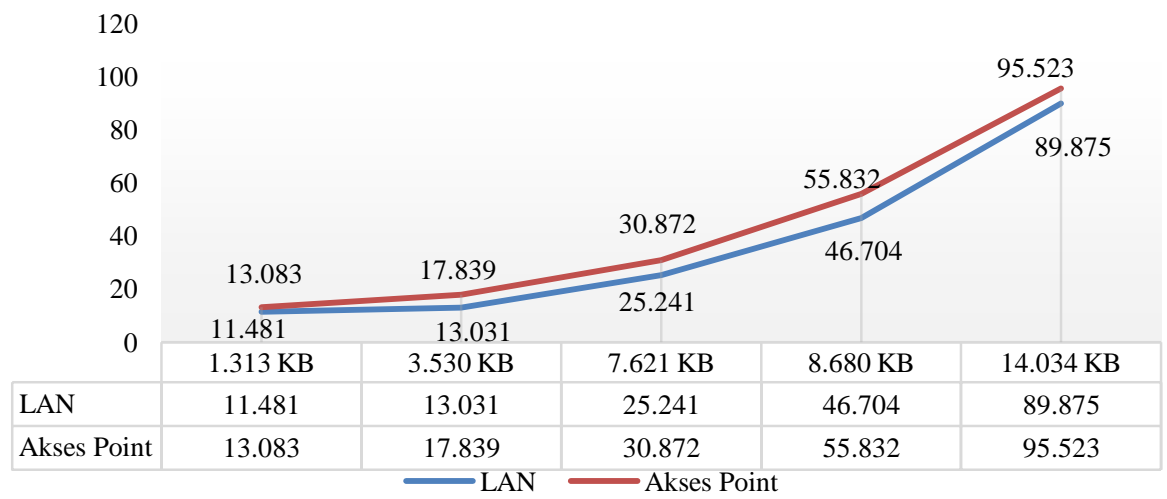

Figure 6. Speed testing chart based on file size and connection type

The third test is the security test of pdf files when the pdf is opened by the user to read. Typically, each browser has a PDF viewer that can be used to open PDF files using a browser. However, the pdf viewer in the browser is very open, and can download, save and print the pdf. Of course, this is not planned since the e-books downloaded for reading by students cannot be reproduced without permission. Therefore, the security tests of a pdf file are tested using third-party download management software.

The test results can be found in Table 3, the test is carried out using 5 software programs by comparing the existing PDF viewer in the browser with the PDF viewer designed for electronic library applications. The results show that from software 5, the pdf sample opened in the PDF viewer for electronic library applications cannot be downloaded. While for the pdf viewer which is in the browser or by default from the browser can not be downloaded also because the web server receives a code as in Figure 7 to block access to pdf files or in folders directly or using the url.

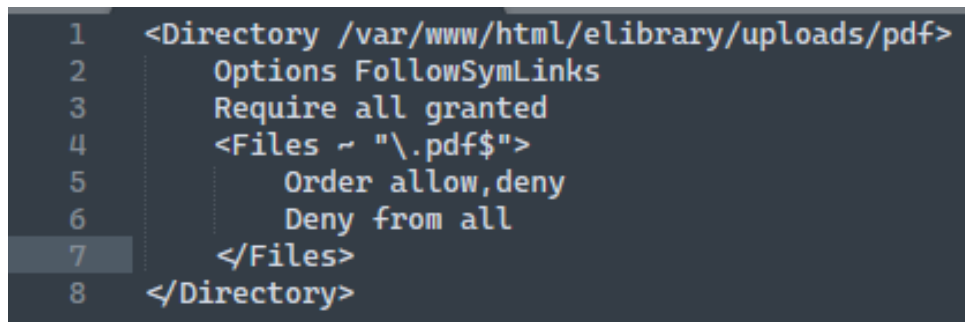

Figure 7. Configuring apache web server to block pdf access

With the use of digital library application, it will make it easier for students to search for books to read, mark readings that have been read, students can also search for keywords they want to see in the book, and can be accessed from anywhere as long as they are connected to the internet. Even though there are many conveniences provided in accessing digital books, it will prevent students from visiting the library directly.

\section{CONCLUSION}

The results of the implementation and testing Library Portable Document Format Javascript that is applied to the e-library application of the Adisutjipto Institute of Aerospace Technology Web-based is capable of blocking illegal downloads. The browser used to access e-library websites can be used to read existing e-books and is able to convert pdf document files into images. Access speed in opening e-books in elibraries is greatly influenced by connection speed, document size, and contents of documents in the form of pictures or writing.

\section{ACKNOWLEDGEMENTS}

Thank you to the library section of STTA which has now become the Adisutjipto Institute of Aerospace Technology (ITDA).

\section{REFERENCES}

[1] S. Sukirno, "Evaluasi pemanfaatan koleksi buku digital oleh mahasiswa pendidikan dokter di Unit Perpustakaan Fakultas Kedokteran Universitas Gadjah Mada (FK UGM)," Berk. Ilmu Perpust. dan Inf., vol. 9, no. 2, pp. 8-17, 2015.

[2] A. M. Aminullah et al., "Pengembangan Koleksi Digital dalam Membangun Perpustakaan Digital di 
Perpustakaan Universitas Islam Negeri Alauddin Makassar," EduPsyCouns J. Educ. Psychol. Couns., vol. 3, no. 1, pp. 58-68, 2021.

[3] R. F. Krzyzanowski and R. Taruhn, "Electronic library for scientific journals: Consortium project in Brazil," Inf. Technol. Libr., vol. 19, no. 2, pp. 61-65, 2000.

[4] I. Beard, "The eBethArké Syriac digital library: a case study," Digit. Libr. Perspect., 2017.

[5] T. Giordano, "Digital resource sharing and library consortia in Italy," Inf. Technol. Libr., vol. 19, no. 2, pp. 84-89, 2000.

[6] T. O. Kolesnykova and O. V Matveyeva, "An Analysis of Digital Library Publishing Services in Ukrainian Universities," 2019.

[7] C.-M. Chen and C. Chang, "A Chinese ancient book digital humanities research platform to support digital humanities research," Electron. Libr., 2019.

[8] R. Wittmann, A. Neatrour, R. Cummings, and J. Myntti, "From digital library to open datasets," Inf. Technol. Libr., vol. 38, no. 4, pp. 49-61, 2019.

[9] K. Palanivel and S. Kuppuswami, "Service-Oriented Reference Architecture for Digital Library Systems," in Cloud Computing and Virtualization Technologies in Libraries, IGI Global, 2014, pp. 255-277.

[10] N. Ahammad, “Open source digital library on open educational resources,” Electron. Libr., 2019.

[11] J. Jamridafrizal, “Online Google Book Sebagai Perpustakaan Digital Alternative Masa Depan,” JIPI (Jurnal Ilmu Perpust. dan Informasi), vol. 2, no. 2, pp. 189-199, 2017.

[12] D. Kristyanto, "PERPUSTAKAAN DIGITAL DAN KELOMPOK PENGGUNA POTENSIAL.," 2019.

[13] Y. Widayanti, "Pengelolaan Perpustakaan Digital," Libr. J. Perpust., vol. 3, no. 1, pp. 125-137, 2015.

[14] A. A. Prakoso, "Implementasi Undang-Undang Hak Cipta No. 28 Tahun 2014 pada Aktivitas Reprografi Koleksi Digital,” Lentera Pustaka J. Kaji. Ilmu Perpustakaan, Inf. dan Kearsipan, vol. 5, no. 1 , pp. 21-31, 2019.

[15] H. Wintolo and A. Farhati, "Pembagian jaringan komputer menggunakan virtual local area network guna mendukung perpustakaan digital," J. Kaji. Inf. Perpust., vol. 8, no. 2, pp. 133-150, 2020. 
